„PRZEGLĄD HUMANISTYCZNY”, 1/2021 ISSN: 0033-2194, e-ISSN 2657-599X

Licencja niewyłączna Creative Commons Uznanie Autorstwa (CC-BY) 3.0 Polska http://creativecommons.org/licenses/by/3.0/pl/ DOI: https://doi.org/10.31338/2657-599X.ph.2021-1.1

\title{
Humanism Under Siege: The Janus Face of the Modern Revolution of Dignity
}

\section{Nina Witoszek}

Oslo University, Norway

e-mail: Nina.witoszek@sum.uio.no

ORCID: 0000-0002-5354-4664

\begin{abstract}
The article interprets the crisis of liberal democracy in the $21^{\text {st }}$ century as the result of an ongoing, dual revolution of dignity. One such revolution is the work of "humanist outliers": small groups and individuals dedicated to compassionate social emancipation. Thus anti-authoritarian revolutions like that of Solidarity in Poland (1980-81) succeed in large part thanks to cultural and political innovations springing from the work of such small groups. However, the humanist revolution of dignity - featuring altruism and cooperation - has its "tribal doppelgänger": a twin revolution that strives to reclaim national dignity and pride at the price of submission to authoritarian rule.
\end{abstract}

\section{Keywords}

Humanism, altruism, small groups, emancipative movements, revolution of dignity

\section{Mapping the Crisis}

There have been numerous interpretations as to why countries like Poland which was the locus of the greatest anti-authoritarian revolution in Europe between 1980 and 1989 - have embraced the 'new authoritarianism' in the second decade of the $21^{\text {st }}$ century. A number of sociologists and historians ${ }^{1}$ have spoken about

\footnotetext{
${ }^{1}$ See, for example, Tadeusz Kowalik, From Solidarity to Sellout: The Restoration of Capitalism in Poland, trans. Eliza Lewandowska (New York: Monthly Review Press, 2012). See also David
} 
the "defeat" and "sell-out" of Solidarność and its key ideals as flowing from the arrogance and selfishness of political and intellectual elites and their indifference to the human costs of neoliberal acceleration. The ongoing retreat of liberal values in $21^{\text {st }}$ century Europe has been labelled a 'counter-revolution' ${ }^{2}$ by Jan Zielonka: a situation where complacent political and intellectual elites are again seen as the villains of the piece. One of Zielonka's proposed remedies is a shift from studies of populism to shining a light on liberal elites' self-image, a quest that would unearth their complicity in manufacturing the incremental derailment of democratic politics.

But there is also research that suggests that fashionable elite-bashing may simplify understanding of the mechanisms behind the neo-authoritarian turn. In a sociological study of a small Polish city that had overwhelmingly voted for the Law and Justice 'neo-authoritarians', the conclusion was that the majority that had voted for the PIS were not paupers or losers, but members of the middle class who did not care about politics: they were anxious to preserve their positions and reclaim "national security and pride". Similarly, feminist scholars, such as Magdalena Środa, unimpressed by the 'arrogant elites' theory, have pointed to the religiously bolstered entrenchment of patriarchy in Polish society and the electorate's political illiteracy - societal flaws that provoke acquiescence in the face of the "rule of imbeciles and priests".

An intriguing interpretation of the current neo-authoritarian turn in Eastern Europe has been offered by Ivan Krastev. ${ }^{4}$ Krastev speaks of parallels between the growth of populist aggression in Eastern Europe and the dynamics of ethnic integration in the West. The first generation usually perceives its integration as a success. Fundamentalism emerges in the second generation, whose representatives were born in the new country. Inevitably, they begin to register the loss of indigenous tradition, the humiliations of being different, as well as noticing weaknesses and derelictions of the hosts to whom their parents had previously looked up. In this reading, the populists in Eastern Europe can be perceived as the 'second generation of immigrants'. This new generation discovers that trying to imitate Western Europe is an unattainable ideal. They are split. One imperative says: 'Be as in the West', the other: 'Don't be a copy, be yourself, Germany is as corrupt as Bulgaria: just think of the Volkswagen scandal'.

There are other, more psycho-social interpretations of the crisis of democracy in Eastern Europe. Andrzej Leder in his Lacan-inspired study of the post-WW2 Poland, ${ }^{5}$ argues that the Polish fascistoid decade in the $21^{\text {st }}$ century has its deep roots in a suppressed, triple trauma linked to the horrors of the twentieth century:

Ost, The Defeat of Solidarity: Anger and Politics in Postcommunist Europe (Ithaca, NY: Cornell University Press, 2006).

2 Jan Zielonka, Counter-Revolution: Liberal Europe in Retreat (Oxford: Oxford University Press, 2018).

3 Magdalena Środa, "Po co kościól obesesyjnie zajmuje się seksem?” Rzeczpospolita, 4 May 2009; Nina Witoszek and Magdalena Środa, "Kvinnelige ofre i nytt katolsk-nasjonalistisk Polen", Aftenposten, 29 May 2016.

${ }^{4}$ Ivan Krastev and Stephen Holmes, The Light that Failed: A Reckoning (London: Allen Lane, 2019); I. Krastev, "Naśladowanie zachodu już się wyczerpało," Gazeta Wyborcza, 28 December 2019, www.wyborcza.pl/naszaeuropa/7,168189,25549011,nasladowanie-zachodu-sie-wyczerpalo.html

${ }^{5}$ Andrzej Leder, Prześniona Rewolucja. Ćwiczenia z logiki historycznej (Warszawa: Wydawnictwo Krytyki Politycznej, 2014). 
a forced transition from a peasant to an urban society; the German extermination of the Jews which benefited large parts of the Polish nation; and the liquidation of the Polish middle classes by the Nazis and the Bolsheviks. All three tragedies have not just led to the 'peasantification' and brutalization of society; they provoked a largely 'unprocessed', savage revolution - orchestrated both by the former German and Soviet occupiers and by the Poles themselves: a symbolic and existential catastrophe that haunts the present. ${ }^{6}$

To move to a broader context, Francis Fukuyama interprets the populist turn not as limited to Orban's Hungary or Kaczyński's Poland, but as rife in a number of societies, from Trumpian America to Modi's India. This regression, Fukuyama argues, is partly a social response to economic and technological shifts of globalization, and partly due to what he calls the 'rise of identity politics' ${ }^{7}$ Before the twenty-first century, politics had been dominated by economic issues; today it is less defined by economic and ideological challenges and more by questions of identity, such as the rights of marginalized groups, immigrants, LGBTs, feminists, or environmentalists. The right, on the other hand, has successfully reinvented itself as a patriotic incarnation of national identity, explicitly connected to race, ethnicity and religion.

Fukuyama's diagnosis is problematic for two reasons. Firstly, one could argue that in the last decades of the twentieth century, the Left gave in to the Right not just by practising identity politics, but by its visionless disregard of important economic issues. Secondly, Fukuyama's panacea - promoting 'creedal national identities ${ }^{8}$ anchored in society's core values and beliefs - ignores the fact that that these values are not necessarily benign. On the contrary, in many cases, they are anchored in resentment and hostility to the Other.

\section{The Dual Revolution of Dignity}

In this essay, I shall argue three points: Firstly, there is, in fact, not one 'counterrevolution', but two revolutions going on simultaneously and polarizing societies in many corners of the world. Though they have different programmes one invoking aggressive tribalism, and the other calling for a more inclusive and humane society - they share the same telos: a profound social desire for dignity, recognition and respect. This desire - captured by the Platonic concept of thymos - is part of human evolutionary equipment. As has been argued by the third wave of evolutionary science, apart from competitive, selfish genes, humans share an altruistic impulse and cooperative skills. ${ }^{9}$ In what is now termed a 'coevolution' equally influenced by genes and by cultural heritage - there is constant feedback

\footnotetext{
${ }^{6}$ Leder, Prześniona Rewolucja, 2014, 10-11.

${ }^{7}$ Francis Fukuyama, "Against Identity Politics: The New Tribalism and the Crisis of Democracy", Foreign Affairs, 97, 5 (2018), 95-115.

${ }^{8}$ Fukuyama, "Against Identity Politics", 106.

${ }^{9}$ For example, Samuel Bowles and Herbert Gintis, A Cooperative Species: Human Reciprocity and Its Evolution (Princeton, NJ: Princeton University Press, 2011); David Sloan Wilson, Does Altruism Exist? Culture, Genes and the Welfare of Others (New Haven, CT: Yale University Press, 2016).
} 
between that part of a culture that strives for reclaiming dignity through cultivating selfish and competitive behaviour, and the other part, which seeks recognition and self-respect through altruistic deeds.

My second point relates to the findings that indicate that the authoritarian turn in Poland after 2015 cannot be seen merely as a reaction to economic hardships. On the contrary, in the second decade of the twenty-first century - before the onset of the Covid 19 Pandemic - all the indices of Polish economic performance were exemplary: one of the highest growth rates in Europe (5 per cent), low unemployment (around 3 per cent) and relatively low Gini coefficient. ${ }^{10}$ We should look for other, pivotal, but non-economic sources of the Polish electorate's support for the despotic regime. ${ }^{11}$ Some of them have to do with a long historical legacy of Poland as a borderline country, suspended between the West and East, and navigating between the experience of being an autonomous agent on the one hand, and a disempowered vassal on the other. This predicament is not just geopolitical but cultural as well, and it has accounted for an enduring national agon: the defenders of the European as well as cosmopolitan dignity have always been challenged by the 'necromancers', feeding national identity with narratives of past wrongs (and, occasionally, doubtful glories) and dreaming of a strongman who would recover national pride and ensure the protection of the national home against the 'alien hordes'.

Thus the revolution which strives to ascribe intrinsic value to women, children, ethnic and gender minorities, and - increasingly - to Nature, clashes with the revolution feeding on a sense of injustice and the cult of the 'whisper of blood, and the pleading of bone', to use Knut Hamsun's metaphor. But, in the last instance, both revolutions are two different responses to modernity's Janus face: one expands the individual self, and the other submits it to the rule of the tribe.

My third point runs counter to the assaults on the elites as the main culprit in the antidemocratic regression. I contend that, certainly in Poland, the nationalist, closed-society movement has been counterpointed by the Polish intelligentsia's ongoing struggle against dehumanizing, authoritarian forces. As I have argued elsewhere $^{12}$, the humanist revolution of dignity is far from being a conceit, projecting Western tastes and values onto the rest of the world. On the contrary, it is a universal, altruistic project - driven by courageous activists, lawyers, teachers, thinkers and artists everywhere - all of them attesting to the better part of our humanity. The non-violent movement that challenges the authoritarian regime by reclaiming human dignity has become as vigorous as the inverse process of the retribalization of the world. It was Godność, Wolność and Solidarność ('dignity', 'freedom' and 'solidarity') that were the rallying cries of the anti-communist Solidarity movement in 1980-81, and the 2014 'Revolution of Dignity' in Ukraine. Similarly, the leaders of the Hong Kong pro-democracy Umbrella Revolution in the same year defined reclaiming human dignity as one of their chief objectives. ${ }^{13}$

\footnotetext{
${ }^{10}$ See OECD data: https://www.oecd.org/sdd/oecdmaineconomicindicatorsmei.htm, 2019.

${ }^{11}$ See Timothy Garton Ash. "It's the Kultur, Stupid," New York Review of Books, 7 December 2017, www.nybooks.com/articles/2017/12/07/germany-alt-right-kultur-stupid/

${ }^{12}$ Nina Witoszek, The Origins of Anti-Authoritarianism (London: Routledge, 2018).

${ }^{13}$ Joshua Wong, the leader of the democratic protesters insisted that 'by vetoing this electoral reform proposal, we are able to keep our dignity'. See Ishi Iyengar, "Barricades are down..." Time, 24 September 2015, www.time.com/4047648/hong-kong-umbrella-revolution-occupy-anniversary/
} 
In 2011 in Cairo, the protesters at Tahrir Square demanded that their rulers give them back their work and their dignity. ${ }^{14}$

That said, in the second decade of the twenty-first century, the humanist revolution of dignity seems to have suffered a dramatic backlash. Most emancipative movements - from Egypt to Libya - plunged back into a dictatorship or a long and vicious war, full of unspeakable bestiality and countless casualties. Poland, once the best pupil in the democratization class, elected a reactionary, nationalist-socialist government in 2015. Needless to say, the crisis of democracy and the resurgence of diverse forms of extremism, have encouraged scepticism about the prospects for a humanist revolution in the twenty-first century. One may ask: what is the point of resistance to dictatorial regimes if the price is so high? Why not wait until influential political players (say, a new Gorbachev), or a concert of great powers change the geopolitical map? Why not conform, consume or condone?

One answer to this question is that, if pragmatic survivalism was the only 'game in town' and stories and rites of dignity stopped being replicated, humanity would have never managed to generate modern, enabling welfare states. The Scandinavian case illustrates that the most successful examples of fair societies are as much products of mixed economies and well-functioning institutions as moral outcomes of strong humanist traditions. ${ }^{15}$ Here I contend that, while there are countless differences between the revolutions of dignity in various corners of the world, the future and sustainability of the humanist revolutions everywhere is ultimately dependent on the existence of small, brave, altruistic groups - the catalysts of change.

\section{The Anti-Authoritarianism of the 'Humanist Outliers'}

Influential studies of the anti-authoritarian mobilization in Poland in 1980-89 have drawn attention to the paramount role of the labour movement, the Catholic Church and religious and political networks. ${ }^{16} \mathrm{I}$ argue that the humanist revolution of dignity happens as it were behind social movements and organized networks. Though the democratic paradigm shift ultimately needs the critical mass of protesters, it is first contemplated and designed in the work of altruist individuals

\footnotetext{
${ }^{14}$ Paul Danahar, The New Middle East: The World after the Arab Uprising (London: Bloomsbury, 2015), 3 .

${ }^{15}$ Nina Witoszek and Øystein Sørensen, "Nordic Humanism and the Welfare State," in Nina Witoszek and Atle Midttun, eds., Sustainable Modernity: The Nordic Model and Beyond (London: Routledge, 2017).

${ }^{16}$ E.g. Neil Ascherson, The Polish August: The Self-Limiting Revolution (New York: Viking Press, 1982); Barbara J. Falk, The Dilemmas of Dissidence in East-Central Europe: Citizen Intellectuals and Philosopher Kings (Budapest: Central European University, 2003); Roman Laba, The Roots of Solidarity: A Political Sociology of Poland's Working-Class Democratization (Princeton, NJ: Princeton University Press, 1991); Maryjane Osa, Solidarity and Contention: Networks of Polish Opposition (Minneapolis: University of Minnesota Press, 2003); David Ost, The Defeat of Solidarity: Anger and Politics in Postcommunist Europe (Cornell University Press, 2006); Alain Touraine et al., Solidarity: Poland 1980-1981 (Cambridge: Cambridge University Press, 1983).
} 
and small groups promoting prosocial attitudes and values. Their vision is often sung by single voices: intellectual savants, religious leaders, writers and courageous ordinary people who do not necessarily organize, but testify to the presence of conscience, compassion and humour in the midst of indignities. Their ranks - in Poland and elsewhere - are endless: the German anti-Nazi theologian Dietrich Bonhoeffer; the Polish iconoclast writer in exile, Witold Gombrowicz; the former Soviet scientist, Andrei Sakharov; the Chinese human rights lawyer, Gao Zhisheng, or the Egyptian stand-up comic, Bassem Yousseff, who challenged the authoritarian regime by 'laughing through the Arab Spring'. Although these groups differ from culture to culture, they share two common features: firstly, they preach and practice altruism and cooperation in the midst of authoritarian oppression - sometimes in the midst of totalitarian hell. ${ }^{17}$ In anthropological terms, these groups and individuals are classical liminars: both $u$ s and them: real or imaginary 'Jews', 'Masons', 'parasites' who are part of us and yet do not belong and do not fit. As social and ethnic suspects - the anomalous, the bizarre, the heretical - they are equipped with creative distance to their habitat, which inspires cultural and political innovation. Hence they enjoy a dual reputation as heroes and pests. On the one hand, they are the source of an energizing, almost dizzying, delight that springs from watching daredevils who make the impossible possible. But they are also perceived as moral blackmailers, provoking a guilty conscience in the mass of the 'gratefully oppressed'. By building islands of individual empathy, autonomy and quirkiness within or outside oppressive structures, they are a constant reminder of how things could or should be. Despite the risks and hazards they face, they keep redesigning a 'dignity script' for their contemporaries and future successors.

Aware of the ongoing philosophical and religious controversy around the concept of humanism, ${ }^{18}$ I define it, broadly, as a worldview that emphasizes the indelible value of humans, cherishes altruism and cooperation, and demands respect for the Other: a mindset which we find not just in the Western Renaissance and Enlightenment but in the cultural archives of numerous traditions. According to the latest evolutionary thought, altruism - as much as its selfish twin - has been latent in human nature and, as such, has functioned as a permanent constitutive factor in the cultural evolution of the human species. ${ }^{19}$ And, although humanism exists in many (religious and secular) versions - each of them modified by a particular cultural context - both its biological moorings and ongoing, global cross-pollination make it into a transcultural project.

One qualification is in order. Fertile humanism celebrates human dignity without idolizing human powers. It steers away both from the perception of humans as a maladapted species and from the delirium of the super-rational and the superhuman. 'It is neither the humanism of a diminished man, nor that of an idealized man monumentally projected against the empty sky' $\cdot{ }^{20}$ It is the humanism

\footnotetext{
${ }^{17}$ It is enough to study the works written by the survivors of Auschwitz, such as Viktor Frankl or Anna Pawełczyńska. See Viktor E. Frankl, Man's Search for Meaning (Boston: Beacon Press, 2006); Anna Pawełczyńska, Wartości a przemoc ('Values and Violence,' Warszawa: Test, 2004).

${ }^{18}$ Marcus Düwell et al., The Cambridge Handbook of Human Dignity: Interdisciplinary Perspectives (Cambridge: Cambridge University Press).

${ }^{19}$ Wilson, Does Altruism Exist? 2016: 5-11.

${ }^{20}$ Andrei Pleşu, "Humanism for the Weak", paper at The Future of Humanism conference, University of Oslo, 4-5 June 2004.
} 
of the Norwegian peasant Hans Nielsen Hauge and his group of 'Friends' whose religiosity and business ethos made an incalculable impact on the emergence of the future welfare society. ${ }^{21}$ But it is also the elitist humanism of secret Masonic lodges that, according to Irene Jacob, ${ }^{22}$ created an intellectual and democratic ferment in seventeenth-century Europe.

The importance of the humanist outliers is not measured by the number of followers, electors or congregations; rather, their actions constitute what Jan Skórzyński in a different context called 'the fifth column of social consciousness'. ${ }^{23}$ They feed and sustain the community's vision of itself as a 'virtuous community' in a world of often harrowing existential constraints. The ways they manage to keep their humanum undamaged despite the inhumanity around them, remains a riddle that has fascinated psychologists, evolutionary scientists and generations of writers from Cervantes to Albert Camus and on to Zbigniew Herbert. Of all the institutional, economic and political remedies against the maladies of the democratic order, these groups constitute the most potent antibodies against the authoritarian virus.

\section{Poland as the Stage of the Humanist Revolution of Dignity}

For all its twentieth-first century derelictions, Poland is an ideal case for studying the efficacy of the humanist outliers. Firstly, it has a long tradition of small, public-minded groups that both created a parallel society within existing oppressive structures and replicated the project of rebuilding the national community by non-violent means. In the eighteenth and nineteenth centuries, after the country had been partitioned by Russia, Prussia and Austria, the humanist outliers kept the idea of a republica emendanda afloat through peaceful and pragmatic means often against the majoritarian propensity for the narratives of national martyrology and encirclement. ${ }^{24}$ The prosocial groups were central to cradling the humanist flame when Poland was a theatre of brown and red totalitarianism in the twentieth century. They were, then, crucial in fostering a parallel society - complete with its education, health system and legal institutions - under the Nazi occupation. After the Second World War, drawing on their earlier oppositional and humanist

\footnotetext{
${ }^{21}$ Nina Witoszek, "The profits and pitfalls of prosociality: cultural-evolutionary perspectives on Scandinavia," in Sakari Hänninen, Kirsi-Marja Lehtelä and Paula Saikkonen, eds., The Relational Nordic Welfare State: Between Utopia and Ideology (Cheltenham: Edward Elgar Publishing, 2019), $50-73$.

${ }^{22}$ Margaret C. Jacob, The Origins of Freemasonry: Facts and Fictions (Philadelphia: University of Pennsylvania Press, 2006).

${ }^{23}$ Jan Skórzyński, Sita bezsilnych. Historia Komitetu Obrony Robotników (Warszawa: Świat Książki, 2012), 20.

${ }^{24}$ See Stańczycy, conservative thinkers attempting to improve Poland's lot under Partitions (1795-1918) via reform rather than armed insurrection. The other group, the so-called Positivists (gathered around the journal, Przeglad Polski), struggled to improve the educational and work conditions of the poorest groups of Polish society.
} 
traditions, they unmasked the evil of Bolshevism and built a microcosm of democracy within the walls of an authoritarian state.

Popular narratives - and most scholarly analysis - have it that the Solidarność revolution was the heroic work of the Polish trade unions who - led by Lech Wałęsa and the Catholic pope - dismantled communist oppression. While this interpretation is not entirely unfounded, a closer look at the trajectory of the Solidarność revolution shows the crucial - and underestimated - work of small groups of courageous humanist renegades.

To exemplify my contention: in the Polish case, one such group was the Workers' Defence Committee, initially a small gathering of 14 friends, lawyers, writers, scholars and students (many with Jewish roots), ${ }^{25}$ who gathered in a Warsaw apartment in the autumn of 1976, and, as usual, drank vodka, seduced women and smoked strong cigarettes, but also talked about the necessity of doing something to help countless destitute families of some 3,000 workers who had been imprisoned by the communist authorities for striking against higher meat prices. The impulse to help the workers was unusual because intellectuals usually give the people what the intellectuals want. However, not this time. The group, led by Jacek Kuron, constituted itself as the Workers' Defence Committee (KOR). They issued an 'Appeal to Society' calling for financial, medical and legal help for the oppressed workers. They published an information bulletin registering every case of communist state ignominy. They went on tedious trips to Radom and Ursus, where they sat through the workers' trials as Samaritan witnesses of communist depravity and mock-justice. They knocked on people's doors, gave out money, brought coal for the winter, and collected names and addresses of victims of state repression.

An in-depth dissection of the KOR's work and strategies of resistance has been offered in numerous scholarly publications. ${ }^{26}$ What I wish to stress here is the paramount role played by a brew of friendship and innovative thinking in the project to restore human dignity in an authoritarian state. This is not to say that KOR was a group of righteous do-gooders who agreed on a virtuous strategy of action. On the contrary, many of them had inflated egos, a penchant for argument and squabble, and a talent for insubordination. They split and improvised as they went along. But whatever their differences, they followed their selfless vision to the end. Already they were forging a new meme: a story about a community that no longer drew on motifs of national victimhood and self-pity, but rather on actions of Shakespearian moral tricksters intent on outsmarting the oppressive state. What KOR and its allies and collaborators did was transforming national self-perceptions from a mere resistance identity to project identity, to use Manuel Castells' pertinent concepts. ${ }^{27}$ 'Resistance identity' is based on shared knowledge about the rotten

\footnotetext{
${ }^{25}$ The members of the original core group included: Jerzy Andrzejewski, Stanislaw Barańczak, Ludwik Cohn, Jacek Kuroń, Edward Lipiński, Jan Józef Lipski, Antoni Macierewicz, Piotr Naimski, Antoni Pajdak, Aniela Steinsberg, Andrzej Szczypiorski, fr. Jan Zieja and Wojciech Ziembiński. As Adam Michnik put it, "We were 70\% Marxist, 80\% Jewish, and 40\% sons and daughters of the red bourgeoisie - often on a war footing with our parents." Personal communication, May 2004.

${ }^{26}$ See Andrzej Friszke, Czas KOR-u: Jacek Kuroń i geneza Solidarności (Kraków: Znak, 2011); Jan Skórzyński, Siła bezsilnych. Historia Komitetu Obrony Robotników (Warszawa: Świat Książki 2012); Dariusz Gawin, Wielki zwrot. Ewolucja lewicy i odrodzenie idei społeczeństwa obywatelskiego 1956-1976 (Kraków: Znak, 2013).

${ }^{27}$ Manuel Castells, Networks of Outrage and Hope: Social Movements in the Internet Age (Cambridge: Polity, 2012), 8.
} 
inefficiency of a despotic and corrupt regime, accompanied by general disbelief that the system would ever disintegrate. 'Project identity', however, is no longer founded on cynicism towards, and hatred of, the oppressive system, but on the forging of a transformative partnership between different, and often conflicting, classes, communities and ideological circles. The new 'creative commons' challenged the idea of living and thinking against the communists. KOR's innovation was to build a micro-community of dignity within the existing authoritarian state. The way forward was to overcome the anti-communist fixation and to invest in a strategy of transcending one's enemy. This transcendence captured so well by Kurt Vonnegut's motto, 'We are what we pretend to be, so we'd better pretend well' - meant, in effect, living as if communist Poland was a free country.

Tirelessly, the KOR task force built alliances with students, Catholics, workers and peasants. Soon, they created their own press bureau, with a link to the BBC, Voice of America and Radio Free Europe, which broadcast every single case of communist brutality. They published underground journals which promoted an uncensored version of Polish, Soviet and European history and established alternative, educational institutions such as The Flying University and its sister, Towarzystwo Kursów Naukowych (The Society of Scholarly Courses). The alliance with the Student Committee of Solidarity ensured a constant influx of young activists.

At the risk of simplifying a complex moral vision, I would roughly distinguish eight pillars of KOR's success: 1) The programme of social solidarity and selforganization designed by Jacek Kuroń in his 'Thoughts about a Program of Action ${ }^{28}$; 2) The reorientation of the oppositional struggle from one directed against the authorities to one focused on creating an independent public sphere as elaborated in Adam Michnik's programme of the 'New Evolutionism';29 3) The Aristotelian-Arendtian conception of politics as a public struggle for values and interests undertaken through peaceful means; 4) The creative reworking of the values of original Christianity as the ethical platform of action, as codified by Kuron in the influential essay 'Christians without God'; ${ }^{30} 5$ ) The dialogic strategy of inter-class and inter-faith dialogue outlined by Michnik in The Church and the Left; ${ }^{31} 6$ ) The imperative of speaking truth to power; 7) The demand of continuous self-education.

What was novel and intriguing about KOR's diffusion of humanist values was that it happened via seduction rather than supplication. The Korowcy enticed leading international poets and thinkers to embrace their vision; they sent endless appeals to influential political leaders in the West; they dazzled students with their wisdom and energy; they persuaded, ironized and cajoled. Most importantly, they found an ingenious way to reach the workers. KOR's Robotnik - a broadsheet circulated in factories and shipyards - repeated ad infinitum one idea that was to

\footnotetext{
${ }^{28}$ Jacek Kuroń, „Myśli o programie działania”, Aneks, London, 13/14 (1977), 33-48.

${ }^{29}$ Adam Michnik, „Nowy ewolucjonizm”, Aneks, 13/14 (1977), 33-48. English version: “A New Evolutionism," in Adam Michnik, Letters from Prison and Other Essays, trans. Maya Latynski (Berkeley, CA: University of California Press, 1985), 135-48.

${ }^{30}$ Jacek Kuroń (aka Maciej Gajka) "Chrześcijanie bez Boga”, Znak, 4/5 (1975), 531-32.

${ }^{31}$ Adam Michnik, Kościół, lewica, dialog (Paris: Instytut Literacki, 1977). English translation The Church and the Left, trans. David Ost (Chicago: University of Chicago Press, 1993).
} 
become the name of the revolution: the idea of 'solidarity'. Solidarity was not just a theoretical concept: it was a tangible social practice that slowly garnered ever more followers.

The result was that suddenly, in the spring of 1980, a parallel society, complete with an independent education system, communication networks and the support of international celebrities, was in place. Gradually, workers, students and peasants abandoned their adaptive 'zombiehood' and joined the unusual group of antiauthoritarian animateurs. It was as if the humanist outliers' acts of solidarity created an 'epidemic of goodness' yielding countless civil initiatives, committees and projects which made a mass of previously 'gratefully oppressed' or intimidated people slowly turn into an enchanted community of citizens.

This did not happen without a price. Many KOR members spent their lives in and out of prison, suffered continuous harassment and lived a life of an ever uncertain tomorrow. Their lot has been most aptly captured in one of the Polish aphorisms: 'Intellectuals are like cream: they are at their best when whipped.'

To sum up: There is no doubt that the Solidarity upheaval was partly possible thanks to the massive mobilization of workers, the visit of the Pope, and outside pressure, both political and moral - such as the Helsinki Declaration - which enabled the dissidents, for the first time in history, to talk about communist violations of human rights. (They also made the authoritarian rulers less enthusiastic in persecuting dissent.) But the tedious and risky preparatory work of planting the idea of social solidarity in a subjugated, passive-aggressive society, keeping the revolution going for the 16 months of Solidarność, and then throughout the 1980s, until the Round Table agreement in 1989, was very much due to the work of small groups of wise individuals. Without their endurance and creative flair, there would have been no Solidarity and no restoring power to the powerless.

\section{The Revolution of Hinterland}

The German concept of Hinterland - referring to 'the land behind' or backcountry - was allegedly first used in 1888 by George Chisholm in his Handbook of Commercial Geography. ${ }^{32}$ But the phenomenon of Hinterland alludes not just to the 'land behind', but also the 'mind behind'. Such a mind feeds on fear and uncertainty that are alleviated by turning to religious dogma or seek refuge in national rites and symbols. In a certain sense, Hinterland is an intriguing evolutionary relic; a re-growth of narratives and sentiments that Enlightenment philosophers thought would be severed by modern ideas. Karl Popper alluded to a retribalization 'which threatens the force of reason, criticism and personal responsibility'. ${ }^{33}$ But Hinterland is not a mere regression: it points towards the enduring potency of society's emotional response to change which cannot be

\footnotetext{
${ }^{32}$ George G. Chisholm, Handbook of Commercial Geography (London: Longmans, Green and Co., 1908).

${ }^{33}$ Karl Popper, The Open Society and its Enemies, vol. 2 (London: Routledge and Kegan Paul, 1945; 1973), 172-74; 251.
} 
banished by social engineering or Fukuyama's promotion of 'creedal identities'. As such, it must be understood as an eternal reaction to modernity's hubris. Democracy is cold; bureaucracy is impersonal and humiliating; the modernizers tend to ignore deep human attachments and allegiances. Feeling surrounded by dangerous, incomprehensible forces and menaced by an uncertain future, the Hinterland begins to take solace in a world where emotional security is guaranteed and the outsiders have no entrance. This world, often invoked by religious and populist leaders, restores nomos, the sacred power of the tribe.

Entrenched in strong, nationalist-Catholic traditions, the Polish Hinterland has been traditionally a source of - interchangeably - exasperation, despair and bad conscience among the Polish intelligentsia. The twentieth-century poet, Aleksander Wat, insisted that at the core of the Polish nation lay 'mass Catholicism, this parochial, obscurantist, and often squalid force, which got purged and more profound in the [soviet] catacombs' ${ }^{34}$ Witold Gombrowicz was equally repelled and spellbound by the natural brutality and robustness of the rabble:

Poland is a grim dream of a madman! ... I'm so amused by this new Soviet Polsha, because, between us, we are still in the early eighteenth century. The nation is dark, Endek ${ }^{35}$ boorish, rebellious, haughty and half-cooked ... and the Kremlin's communism has been grafted upon it. ${ }^{36}$

In a compelling account of his early life, Czesław Miłosz offers an especially desperate perception of his countrymen:

If I was given a means, I would explode this country, so that mothers would stop mourning those killed on the barricades ... Because there is a species of pity which nobody can bear. ${ }^{37}$

Interestingly, well into the 1960s, part of the Polish intelligentsia (especially those living in exile), however, horrified by the prospect of a communist future, argued that a non-communist Poland would be even worse. The September 1968 issue of the exile journal Kultura, includes an essay criticizing Kuroń and Modzelewski's infamous 'Letter to the Communist Party' demanding free and democratic elections. Such elections, the Kultura author argues, would lead to replacing the socialist system "not by parliamentary democracy but a right-wing dictatorship and a fascistoid totalism' (sic!). ${ }^{38}$

Three qualifications are in order. Firstly, the quoted assaults on the Polish Hinterland do not necessarily imply a lack of patriotism. More often than not, they testify to being 'hurt' by Poland, in the same way, Joyce was hurt by Ireland

\footnotetext{
${ }^{34}$ Aleksander Wat, My Century: The Odyssey of a Polish Intellectual, with a foreword by Czesław Miłosz, trans. Richard Lourie (Berkeley: University of California Press, 1988), 48.

${ }^{35}$ Endek is an acronym of the 'National Democracy' movement promoted in the 1930 s by the right-wing politician Roman Dmowski and linked to the Polish radical-fascist and anti-Semitic circles.

${ }^{36}$ Witold Gombrowicz, A Kind of Testament, ed. Dominique de Roux, trans. Alastair Hamilton (London: Alder and Boyars, 1973), 34, 42.

${ }^{37}$ Czesław Miłosz, Native Realm: A Search for Self-Definition, trans. Catherine S. Leach (New York: Farrar, Straus and Giroux, 1959; 2002), 273.

${ }^{38}$ This convinced some Kultura intellectuals (like Edward Mieroszewski) that for the sake of a more humane future, it was better to tolerate Soviet communism than to let democracy loose. See Dariusz Gawin, Wielki Zwrot: Ewolucja i odrodzenie idei społeczeństwa obywatelskiego (Kraków: Znak, 2013), 130-31. Mark Brzeziński, The Struggle for Constitutionalism in Poland (London: MacMillan Palgrave, 2000).
} 
and Ibsen by Norway. Secondly, they point, if only indirectly, to a durable chasm between the Polish intelligentsia and the working class. Thirdly, the brutal selfscrutiny of the Polish writers together with often quoted references to ostensibly innate Polish xenophobia and anti-Semitism, need a bit of nuancing. It is more justified to speak of two parallel strains in Polish culture: one introvert and advancing nationalist-Catholic bigotry, and the other inclusive, highlighting tolerance and pluralism. The latter tradition goes back to the Renaissance and the so-called Warsaw Confederation of 1573, which yielded a pioneering codification of religious tolerance in Europe. ${ }^{39}$

The Solidarność revolution in 1980 suspended, at least for a time, the profound interclass animosities. It bragged a charismatic leader who seemingly united all classes around an anti-authoritarian project: Lech Wałęsa, a humble, moustachioed man from the Gdansk shipyards who took over the revolution as a charismatic tribune of the striking workers. He was almost invented for the occasion: charming and funny, a mixture of a lion and a fox, determined and yet cautious, purging the Orwellian newspeak of its wooliness and woodiness. Initially, an incarnation of folk wisdom, Walesa seduced both the pious and the beautiful minds. But increasingly, as he grew into the role of the first president of democratic Poland, it became apparent that he was hardly a dialogic politician: he was a genius of the Hinterland. Admittedly, he represented a soft, palatable version of the earthly virtues and vices of the 'mind behind'. He was not a rabid Catholic nationalist, though he insisted that he incarnated the nation. He was not a fundamentalist Catholic, though he demonstratively wore an image of Holy Virgin on his lapel and listened avidly to Radio Maryja. He was not an anti-Semite, though he occasionally differentiated between 'Jews, gays and the white people'. But, above all, he was a master of blunders cum aphorisms, the most famous being: 'I am for, even against'; 'It's good that what's happened is bad'; 'There are negative pluses and positive minuses of this situation'. ${ }^{40}$

Some observers claim that Walesa's metamorphosis into a pompous buffoon was the result of power going to his head. Though this may be partly true, Wałęsa's moral progress (or rather, regression) can be seen as the gradual unfolding of the dark core of the Hinterland: seductive, but also wounded, paranoid, insulted, disdainful and authoritarian. ${ }^{41}$

The Hinterland revolution in the post-Solidarity time - aiming to restore the dignity of the tribe - has been a result of multiple, political, economic and cultural forces. As mentioned above, most social scientists talk about the accelerated and brutal socio-economic transformation which leads to the existential destabilization of thousands of people and the emergence of the homo sacer: $:^{42}$ a superfluous and 'redundant' man and woman, a lame consumer without hope or perspective of

\footnotetext{
${ }^{39}$ See Mark Brzeziński, The Struggle for Constitutionalism in Poland (London: MacMillan Palgrave, 2000); Ole Peter Grell and Bob Scribner, eds. Tolerance and Intolerance in the European Reformation (Cambridge: Cambridge University Press, 2002), 264; Mirosław Korolko and Janusz Tazbir, eds., Konfederacja warszawska 1573 roku. Wielka karta polskiej tolerancji (Warszawa: Instytut Wydawniczy PAX 1980).

40 Jerzy Bralczyk, "O języku Wałęsy.” Teksty Drugie. 4 (1990), 60-81.

${ }^{41}$ Interestingly, Wałęsa's refreshing anti-authoritarianism returned only when his country embraced authoritarian rule in 2015. He was then 69 , his former status as a national hero in tatters.

${ }^{42}$ Giorgio Agamben, Homo Sacer: Sovereign Power and Bare Life, trans. Daniel Heller-Roazen (Stanford, CA: Stanford University Press, 1998), 17.
} 
a better future. The Hinterland becomes further inflamed as a result of what Roger Griffin calls 'a nomic crisis' (a crisis of meaning) due to the threats to home, belonging and society's self-respect. ${ }^{43}$ Perceiving outsiders - whether from inside or outside the nation - as not so much enemies but wrongdoers, the Hinterland feeds its wounded identity on vindictive inhumanity.

But there has been yet another source of the Hinterland revolution in Poland, one that has to do with the psychological makeup of post-authoritarian people. One cannot forget that post-Solidarity Poland was a society that had been methodically infantilized by communist regimes, often ruled by imbeciles, and trained in a passive-aggressive stance vis-à-vis the outside world, rather than in cultivating a proactive or positive mindset. Far from creating a new socialist man, free of egotism and greed, communism actually bred atomized, amoral cynics good at doublethink, 'working the system' and replicating the communist narratives about the alleged wickedness and arrogance of the intellectual elites: the true enemies of the people.

Hence the Eastern European rage against the educated classes - although part of the general feature of twenty-first-century populisms - has different sources than, say in the US or France. To take the Polish case, the post-communist public anger has been also directed at the people who - unlike the passive majority - had actually fought and suffered for the democratic order and more humane society. And here lies the crux of the matter. The Eastern European Hinterland is a community that does not understand the courage of altruist heroes - it needs to rationalize this courage, banalize it, or make it suspect to finally throw it out of the national memory.

The accurate reconstruction of the relationship between the revolution aspired to by humanist outliers and the rising of the Hinterland is a tricky heuristic challenge. Paulo Freire in his famous Pedagogy of the Oppressed, insisted that:

The man or woman who proclaims devotion to the cause of liberation yet is unable to enter into communion with the people, whom he or she continues to regard as totally ignorant, is grievously self-deceived. The convert who approaches the people but feels alarm at each step they take, each doubt they express and each suggestion they offer, and attempts to impose his 'status', remains nostalgic toward his origins. ${ }^{44}$

This is a problematic statement. According to those who think along Freire's lines, by condemning the intolerant nationalism of the Hinterland, intellectuals risk distancing themselves from the people, fuelling social resentment, and thus exacerbating populism and racism. ${ }^{45}$ This is an unsettling diagnosis. Firstly, it posits the role of the intellectual elites as the 'doctors of the national soul' rather than votaries of inconvenient truths. Secondly, forging class solidarity in the fight against the common enemy cannot be confused with courting the people as end in itself. As Michnik pointed out:

\footnotetext{
${ }^{43}$ Roger Griffin, ed., Fascism, Totalitarianism and Political Religion (London: Routledge, 2005).

${ }^{44}$ Paule Freire, The Paulo Freire Reader, eds. Ana Maria Araujo Freire and Donaldo Macedo (New York: Continuum, 1988), 59.

${ }^{45}$ See especially Agata Bielik-Robson, "Obrona kołtuna," Krytyka Polityczna, 1 (2002), 85-100; Dariusz Gawin, "Inteligenckie obrachunki epoki transformacji," Krytyka polityczna, 1 (2002), 94-111; Zdzisław Krasnodębski, Demokracja peryferii (Gdańsk: Słowo/obraz terytoria, 2005).
} 
If you finally arrive in the Poland of your dreams, you have to defend her and protect her against demagogy, stupidity, irresponsibility, and anarchy ... [n]ot let yourself be pushed into extremist positions. You have to use peaceful means in building relations between people and neighbours. ${ }^{46}$

Last but not least, the concept of the class communion couched by Freire gestures towards a lyrical socialist belief that one can cure a fanatic. Such a belief implies that if Michnik and his Gazeta Wyborcza had not scolded the postSolidarność priests and prophets who wanted to rid Poland of 'Jewish contamination', there would be no populism in the $21^{\text {st }}$ century Poland. It is enough to think of a grand 2002 national celebration involving the Polish Primate and representatives of all political parties - all bathing in banners and flowers - where the leader of the Ursus branch of Solidarność, Zygmunt Wrzodak declared:

The pink political hyenas from KOR, free-riding on the workers, the Church and the Motherland, had only one aim: to grab power, using the workers as their tool. Kuron, Michnik and comrades, in their zoological hatred of Polishness, cynically played out our misfortune, blood and innocence. Their help was a Pharisee's attempt to buy themselves into our Polish, Catholic, working class environment. They did all this in order to strike an agreement - behind our backs with their ideological kinsmen, the communists. ${ }^{47}$

When seen in the context of this and many similar assaults on the architects of free and democratic Poland, there is actually something both distressing and energizing about the humanist outliers' efforts to resist the temptation of being 'popular' and playing into the likes of Wrzodak. What is distressing is their despair with the amnesiac ingratitude of people whom they had once defended and risked their lives for. What is energizing is their struggle to keep standards of excellence and unselfish action in the face of narrow-mindedness and dogma. The charge of ostensible 'elitism' - or the epithets of the 'Warsaw salon', so often used in reference to former KOR members - collapse when we consider that most of them had spent large chunks of their lives in prison or performed punitive, degrading jobs in industrial workplaces. Their 'normality' was less about armchair meditation and more about fraternizing with the working classes in ways that had been far from elevating or inspiring. ${ }^{48}$ To reproach the oppositional intelligentsia for running 'elitist salons' is not only to banalize the humanist outliers' acts of bravery and self-sacrifice, but to distort national history and memory.

What I am arguing here is that exploring the voices of the oppressed calls for a nuanced approach that avoids the pitfalls and clichés both of postcolonial studies and Marxist good people vs bad elites theorizing. It also demands rethinking the strategy of defending the humanist values in the context of robust, triumphant Hinterland. It needs to take into account that the 'new authoritarians' come in two flanks. One of them includes the victims of inequality which is on the increase,

\footnotetext{
${ }^{46}$ Adam Michnik, Wściekłość $i$ wstyd (Kraków: Znak, 2005), 33. My translation.

${ }^{47}$ Artur Domosławski, "KOR: Hieny, zdrajcy, terroryści," Gazeta Wyborcza, 21 Sept. 2001, My translation, www.wyborcza.pl/1,76842,444838.html.

${ }^{48}$ Jacek Kuron wrote to his wife Gaja: '[After all this time] I experience prison to the umpteenth power. Not by sympathizing with the "professionals of crime" but by trying to feel myself into their way of seeing the world, their lives and pasts. In these lives there had been no room for friendship, love, or human feelings. And suddenly, in this sump, I discover a human being - his dreams and longings - and the landscape becomes even darker' (Karta 1969, samizdat). My translation.
} 
if only, because - as Zygmunt Bauman has observed - 'What liberal society offers with one hand, it tends to take back with the other" (Bauman 1996: 82). The other flank, as Gdula's study has demonstrated, is the often relatively prosperous community of middle-class citizens who - apart from being morally provoked by the cosmopolitanism, corruption and complacency of economic, political and intellectual elites - are willing to trade their freedoms for greater personal and collective security. The Hinterland revolution - and the majoritarian consent granted to the PiS government's dismantling of democracy - points towards the potency of emotional responses to potential or imaginary threats which cannot be banished by social engineering or re-education alone, as Fukuyama suggests. It must be understood both as the expression of tribal thymos, i.e., the resentful community's desire for respect and recognition, and as the result of - and response to - a world in which altruism and civility had been prosecuted rather than rewarded. It is in the harsh, postcolonial and postcommunist conditions that the work of small groups that maintain the humanist revolution of dignity becomes doubly so important.

\section{Conclusions: The 'Terrible Beauty' of Humanism}

In the second decade of the $21^{\text {st }}$ century, groups and individuals who fight for an inclusive, tolerant society, face a double Herculean task: both to challenge the mythology of the tyrannical centre and to reinvent the often ossified and polarizing narratives that the oppressed themselves hold sacred and are unwilling to tweak or refashion. ${ }^{49}$ Each disempowered and homeless community desperately clings to its tribal, nationalist and religious myths; they are its shelter, its axis mundi, a source of consolation. They stabilize the glaring chaos that cannot be ordered without an injection of mythical energy. This means, in effect, that both the authoritarian and anti-authoritarian myths, like all myths, do not just unite people but divide them as well, creating walls between them. They do not speak the language of argumentation and reason; they override both.

This does not mean that the humanist revolution of dignity is a doomed project. As I have argued above, between 1976 and 1989 an extraordinary gathering of political and literary talent - thinkers, poets and activists from all social strata set out to restore human autonomy in an authoritarian state. Much of their work was barely recorded on cameras or anatomized by political scientists. Rather, it constituted the revolution behind the revolution: an invisible, ongoing transformation that slowly erodes all authoritarian regimes and which, seemingly, has no direct political or economic telos. It advances and retreats and advances again. It does not belong to the progress of democracy but the moral progress of humanity. It is

\footnotetext{
${ }^{49}$ One such Polish master narrative springs from the mythology about an ethnically pure, heroic and Catholic Poland - unsullied by the Jews and foreign capital - marshalled by the pre-WWI political movement Endecja ('National Democracy'). In post-war history, the stories and rites of Endecja were buried and disinterred and buried again, depending on their political expediency. Since 2015, the nationalist, xenophobic and authoritarian topos became part of the PiS party's founding myth.
} 
a revolution that augments, and constantly refines, the idea of a 'community of conscience'. It also challenges those who share the conviction that life is determined by forces outside the individual Self, its interests, and its wishes.

Thus, on the one hand, the sense of powerlessness, and the loss of the self, whether in communist fantasies, right-wing religiosity, or modern jihadism, has been on the rise in the second decade of the twenty-first century. But they have also been opposed at every turn by the humanist animateurs: from the Sudanese protesters against the dictatorship of Omar Al-Bashir in 2019 and decades of tyranny and plunder, to the audacious reporters who expose Angola's kleptocracy or Syrian atrocities. Their struggle is invaluable: a testimony both to the value of altruism and cooperation, and, paradoxically, to the inhumanity of the humanist ethos. Today we return to 'dignity', the central concept of the Renaissance, often not realizing the painful wisdom and frightening cost of humanism in action the humanism which is not about being a winner, or even a survivor, but about the burden of being a carrier of humanum in humanity. It is enough to listen to Michnik, who in 1989, during the time of 'freedom rising', made one of those discerning, oracular statements for which he has been known: forging a humanist, European Poland, he argued, involves:

carrying within yourself an acceptance that you'll be an object of slander, that the bad tongues will accuse you of contempt for your nation and betrayal of national values. In other words, if you want to be faithful to the truth and sceptical towards the herd, you'll have to inscribe your fate into a vision which includes a harsh sentence for outraging your fellow brothers. A sentence that was Socrates's lot. ${ }^{50}$

One could argue that the seeming triumph of the Hinterland in Poland violating individual rights, politicizing the courts, media and schooling, creating LGBT free zones, and actively despising the feminists, 'genderists,' ecologists and cyclists - seems to render the Socratic project futile, if not downright suicidal. However, if the proponents of evolutionary thought are right - and it is cooperation and altruism that make society more resilient and create antibodies against the totalitarian temptation - then the humanist animateurs' work is the only guarantee of a better, more sustainable future.

To sum up: Like many other countries in the world, twenty-first century Poland is the stage of two revolutions of dignity. One is rooted in resentment, tribal solidarity and the memory of past wrongs which feed into illiberal movements. But we cannot ignore the other, humanist revolution, propelled by the ancient virtues of the humanist outliers. However anachronistic they seem to the digital-pragmatic generations, they do make overcoming the authoritarian scourge into an imaginable and viable project. As Ann Norton has argued, virtuous acts, although defeated, do not vanish; they present alternatives that can be taken up again in an altered form. They are "possibilities preserved because both the memory of the victory and the identity of the victor depend on that which was overcome'. ${ }^{51}$ Hannah Arendt said as much: 'The good things in history are usually of very short duration, but afterward have a decisive influence on what happens over long periods of time'. ${ }^{52}$

\footnotetext{
${ }^{50}$ Adam Michnik, Diabel naszego czasu (Warszawa: Nowa, 1995), 289. My translation.

${ }^{51}$ Anne Norton, 95 Theses on Politics, Culture and Method (New Haven, CT: Yale University Press, 2004), 49.

${ }^{52}$ Hannah Arendt, Crises of the Republic (New York: Harcourt Brace Jovanovich, 1972), 204.
} 


\section{References}

Agamben, G. Homo Sacer: Sovereign Power and Bare Life, trans. Daniel Heller-Roazen. Stanford University Press, 1998.

Arendt, H. Crises of the Republic. New York: Harcourt Brace Jovanovich, 1972.

Ascherson, N. The Polish August: The Self-Limiting Revolution. New York: Viking Press, 1982.

Ash, T. G. "It's the Kultur, Stupid," The New York Review of Books, 7 December 2017, www. nybooks.com/articles/2017/12/07/germany-alt-right-kultur-stupid/

Bielik-Robson, A. "Obrona kołtuna," Krytyka Polityczna, 1 (2002), 85-100.

Bralczyk, J. "O języku Wałęsy.” Teksty Drugie. 4 (1990).

Brzeziński, M. The Struggle for Constitutionalism in Poland. London: MacMillan Palgrave, 2000.

Danahar, P. The New Middle East: The World after the Arab Uprising. London: Bloomsbury, 2015.

Düwell, M., et al. The Cambridge Handbook of Human Dignity: Interdisciplinary Perspectives. Cambridge: Cambridge University Press, 2014.

Bowles, S., and Gintis, H. A Cooperative Species: Human Reciprocity and Its Evolution. Princeton, NJ: Princeton University Press, 2011.

Castells, M. Networks of Outrage and Hope: Social Movements in the Internet Age. Cambridge: Polity, 2012.

Chisholm, G. Handbook of Commercial Geography. London: Longmans, Green and Co., 1908.

Domosławski, A. “KOR: Hieny, zdrajcy, terroryści," Gazeta Wyborcza, 21 Sept. 2001, www.wyborcza. $\mathrm{pl} / 1,76842,444838 . h \mathrm{tml}$

Falk, B. J. The Dilemmas of Dissidence in East-Central Europe: Citizen Intellectuals and Philosopher Kings. Budapest: Central European University, 2003.

Frankl, V. Man's Search for Meaning. Boston: Beacon Press, 2006.

Freire, P. The Paulo Freire Reader, eds. Ana Maria Araujo Freire and Donaldo Macedo. New York: Continuum, 1988.

Friszke, A. Czas KOR-u: Jacek Kuroń i geneza Solidarności. Kraków: Znak, 2011.

Gawin, D. Wielki zwrot. Ewolucja lewicy $i$ odrodzenie idei społeczeństwa obywatelskiego 1956-1976. Kraków: Znak, 2013.

Gawin, D. "Inteligenckie obrachunki epoki transformacji," Krytyka polityczna, no. 1 (2002), 94-100.

Gombrowicz, W. A Kind of Testament, ed. Dominique de Roux, trans. Alastair Hamilton. London: Alder and Boyars, 1973.

Grel, O. P., and Scribner, B., eds. Tolerance and Intolerance in the European Reformation. Cambridge: Cambridge University Press, 2002.

Griffin, R., ed. Fascism, Totalitarianism and Political Religion. London: Routledge, 2005.

Fukuyama, F. "Against Identity Politics: The New Tribalism and the Crisis of Democracy," Foreign Affairs, 97, 5 (2018), 95-115.

Iyengar, I. "Barricades are down..." Time, 24 September 2015, www.time.com/4047648/hong-kongumbrella-revolution-occupy-anniversary/

Jacob, M. C. The Origins of Freemasonry: Facts and Fictions. Philadelphia: University of Pennsylvania Press, 2006.

Korolko, M., and Tazbir, J., eds. Konfederacja warszawska 1573 roku. Wielka karta polskiej tolerancji. Warszawa: Instytut Wydawniczy PAX 1980.

Kowalik, T. From Solidarity to Sellout: The Restoration of Capitalism in Poland, trans. Eliza Lewandowska. New York: Monthly Review Press, 2012.

Krasnodębski, Z. Demokracja peryferii. Gdańsk: Słowo/obraz terytoria, 2005.

Krastev, I., and Holmes, S. The Light that Failed: A Reckoning. London: Allen Lane, 2019.

Krastev, I. "Naśladowanie zachodu już się wyczerpało," Gazeta Wyborcza, 28 December 2019, www.wyborcza.pl/naszaeuropa/7,168189,25549011,nasladowanie-zachodu-sie-wyczerpalo.html

Kuroń, J. "Myśli o programie działania,” Aneks, London, 13/14 (1977), 33-48.

Kuroń, J. (aka Maciej Gajka) "Chrześcijanie bez Boga," Znak, 4/5 (1975), 531-32.

Laba, R. The Roots of Solidarity: A Political Sociology of Poland's Working-Class Democratization. Princeton, NJ: Princeton University Press, 1991. 
Leder, A. Prześniona Rewolucja. Ćwiczenia z logiki historycznej. Warszawa: Wydawnictwo Krytyki Politycznej, 2014.

Michnik, A. "Nowy ewolucjonizm," Aneks, 13/14, 1977, 33-48.

Michnik, A. Letters from Prison and Other Essays, trans. Maya Latynski. Berkeley, CA: University of California Press, 1985.

Michnik, A. Kościót, lewica, dialog. Paris: Instytut Literacki, 1977. English translation: The Church and the Left, trans. David Ost. Chicago: University of Chicago Press, 1993.

Michnik, A. Wściektość i wstyd. Kraków: Znak, 2005.

Michnik, A. Diabet naszego czasu. Warszawa: Nowa, 1995.

Miłosz, Cz. Native Realm: A Search for Self-Definition, trans. Catherine S. Leach. New York: Farrar, Straus and Giroux, 1959; 2002.

Norton, A. 95 Theses on Politics, Culture and Method. New Haven, CT: Yale University Press, 2004.

OECD data: https://www.oecd.org/sdd/oecdmaineconomicindicatorsmei.htm, 2019.

Ost, D. The Defeat of Solidarity: Anger and Politics in Postcommunist Europe. Ithaca, NY: Cornell University Press, 2006.

Osa, M. Solidarity and Contention: Networks of Polish Opposition. Minneapolis: University of Minnesota Press, 2003.

Pawełczyńska, A. Wartości a przemoc ("Values and Violence"). Warszawa: Test, 2004.

Pleşu, A. "Humanism for the Weak," paper at The Future of Humanism conference, University of Oslo, 4-5 June 2004.

Popper, K. The Open Society and its Enemies, vol. 2. London: Routledge and Kegan Paul, 1945; 1973.

Skórzyński, J. Siła bezsilnych. Historia Komitetu Obrony Robotników. Warszawa: Świat Książki, 2012.

Środa, M. "Po co kościól obesesyjnie zajmuje się seksem?” Rzeczpospolita, 4 May 2009.

Wat, A. My Century: The Odyssey of a Polish Intellectual, with a foreword by Czesław Miłosz, trans. Richard Lourie. Berkeley: University of California Press, 1988.

Wilson, D. S. Does Altruism Exist? Culture, Genes and the Welfare of Others. New Haven, CT: Yale University Press, 2016.

Witoszek, N., and Środa, M. "Kvinnelige ofre i nytt katolski-nasjonalistisk Polen," Aftenposten, 29 May 2016.

Witoszek, N., and Sørensen, Ø. "Nordic Humanism and the Welfare State." In Nina Witoszek and Atle Midttun, eds., Sustainable Modernity: The Nordic Model and Beyond. London: Routledge, 2017.

Witoszek, The Origins of Anti-Authoritarianism. London: Routledge, 2018.

Witoszek, N. "The profits and pitfalls of prosociality: cultural-evolutionary perspectives on Scandinavia." In Sakari Hänninen, Kirsi-Marja Lehtelä and Paula Saikkonen, eds., The Relational Nordic Welfare State: Between Utopia and Ideology. Cheltenham: Edward Elgar Publishing, 2019, 50-73.

Zielonka, J. Counter-Revolution: Liberal Europe in Retreat. Oxford: Oxford University Press, 2018. 